\title{
WOORDVERWISSELING BIJ BESMETTELIJKE ZIEKTEN ONDER DE TOBELOREEZEN.
}

DOOR

\author{
A. HUETING.
}

In het district Tobèlo hebben hevig de pokken gehcerscht. Natuurlijk dat de toovenaars tegenover die ziekte machteloos staan, naar aangezieu dergelijke lieden hun oumacht nooit erkenuen, weten zij gewoonlijk wel een loopje te vinden om het niet gunstig werken hunner medicijnen te verklaren. $N u$ verklaarden zij de pokziekte voor een roudreizend Vorst, machtiger dan de gewone ziekmakende geesten, tegenover welke meu dus wal machteloos moest zijn. Het eigenaardig gevolg hiervan was nu, dat plotseling algemeen een nieuwe terminologie voor de ziekte ingevoerd werd, volkomen in overeenstemming met die toovenaarstheorie. De gewone naam voor pokken is o luti, en de pokken hebben: $i$ na luti. Onder dien naam sprak men dan ook in den beginue van de ziekte en diegenen welke een vervangwoord moesten gebruiken (omdat het woord luti voorkomt in de namen hunner schooufamilie) spreken van de ziekte als o bobàku: besmettelijke ziekte. Eeus echter kwam een vrouw om medicijuen vragen voor iemand waut: o Djou moi wi bò̀ka: er was een heer tot hem gekomen. Sinds hoorde ik den eigenlijken naam der ziekte door Heidenen of Mohamedamen niet meer noemen. Algemeen zeide men van iemand die de pokken had: wa tjoungu: hij verricht heereudienst. Voor het opkomen van den uitslag zeide men niet meer het gewone $i$ puda; het komt op : of het kount boven, maar: ài Djou wi poòtokòka: zijn heer is hem, of bij hem uitgebarsteu. Stierf iemand aan de ziekte, dan gebruikte men niet het gewoue: ho hònĕnge: sterven, maar men zeide, wo hidetòka : hij is weggezeild, of weggevaren. Voor het hersteld zijn van de ziekte, zeide men niet als gewooulijk: o penjakit $i$ togumòka: de ziekte is opgehouden, of : o penjakit $i$ àikòka: de ziekte is uit (het lichaam) genomen, maar: wa bòtokk : hij is ermede klaar, waarbij 
natuurlijk gedacht wordt aan den verrichtten heerendienst, of ook: wo ma òhikòka: hij heeft zich gebaad, 't geen men natuurlijk doet na een volbrachte dagtaak. Nu baadde men zich ook werkelijk na de ziekte (gewoonlijk veel te vroeg om te toonen, dat de taak af was) maar toch zou men ten opzichte van eene andere ziekte niet op die manier de genezing uitgedrukt hebben.

Men had of heeft nog meer dergelijke woorden, maar de boven gegevene zijn de voornaamste. Als redenen waarom men aldus sprak gaf men op: Men mocht over den Heer niet spreken als over een gewone ziekte, dat zou hem zeker vertoornen. 't Was dus om hem in een goede luim te houden. 't Is natuurlijk, dat men van die beschouwing ook in daden blijk gaf. Kreeg iemand de ziekte in een huis aan den hoofdweg gelegen, dan bracht men den patient naar een tuinhuisje, want de ziekte was een Heer, die natuurlijk niet in een tuinhuisje maar aan den grooten weg wilde wonen. Door het plaatselijk Bestuur was gelast, dat besmette huizen moesten worden aangeduid door een wit vlaggetje. Dra zag men van alle huizen een vuile witte lap wapperen: de Heer moest niet denken, dat men zich voor zijn vlag schaamde! De vruchten der Spaansche peper en der tomaten moesten opgeruimd, omdat die wel iets op uitkomende pokken lijken, en de Heer mocht eens denken, dat men hem bespotte door zijn teekenen na te bootsen!

En nog meer dergelijke. Maar dat alles komt meer voor. Waarop ik echter in 't bijzonder de andacht wil vestigen, is die plotselinge woordverwisseling. Men kan gerust zeggen, dat die terminologie in een paar dagen zich over de heele besmette streek verbreid had.

$\mathrm{Ik}$ weet niet of aualoge gevallen bekend zijn, maar het komt me voor dat de gewoonte van deze volken om met wissel- of vervangwoorden te spreken (ho hohono) er veel toe bijgedragen heeft, de nieuwe terminologie zoo spoedig in te burgeren.

Tobèlo, Februari 1909. 